\title{
Distribution, composition and seasonality of aquatic birds in the Nhecolândia sub-region of South Pantanal, Brazil
}

\author{
Donatelli, RJ. ${ }^{a}$, Posso, SR. ${ }^{b *}$ and Toledo, MCB. ${ }^{c}$ \\ áLaboratório de Ornitologia, Departamento de Ciências Biológicas, Faculdade de Ciências - FC, \\ Universidade Estadual Paulista - UNESP, Caixa Postal 473, CEP 17001-970, Bauru, SP, Brasil

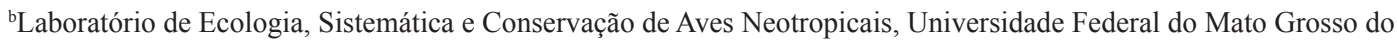 \\ Sul - UFMS, Av. Ranulpho Marques Leal, 3484, Caixa Postal 210, CEP 79620-080, Três Lagoas, MS, Brazil \\ 'Instituto de Biociências, Universidade de Taubaté - UNITAU, Av. Tiradentes 500, CEP 12010-180, Taubaté, SP, Brazil \\ *e-mail: srposso@hotmail.com
}

Received: April 4, 2013 - Accepted: July 15, 2013

(With 3 figures)

\begin{abstract}
Despite remarkable significance of Pantanal for the conservation of aquatic birds, the status of their populations, the spatiotemporal patterns of distribution and habitat use and structure of communities are little known. Thus, we studied three aquatic environments (Negro river, bays and salines) from 2007 to 2009 in the Nhecolândia Pantanal to verify the distribution and composition of aquatic birds and also if there is significant seasonal influence on these aspects. We adopted the transect method (288 hours of sampling) and recorded 135 species (7.834 individuals). The Negro river showed the highest diversity, while the salines the lowest. The similarity of aquatic bird communities was higher between bays and salines, followed by Negro river and bays and lower between salines and Negro river. The equidistribution is more variable in the salines and more stable in the Negro river. The environments strongly differ from each other in aquatic bird composition in space (habitat use and distribution) and time (seasonal water fluctuations). The diversity of bird community in the dry season varies significantly in the salines, followed by the bays and more stable in the Negro river. The Negro river, regardless of large annual amplitude of flow, is more seasonally stable since its riparian vegetation is continuous (not isolated) and constant. These aspects provide better conditions to stay all year, contributing to decrease the seasonal nomadic tendencies of aquatic birds. Finally, all these data provide strong arguments to the preservation of all phytophysiognomies in the Nhecolândia sub- region of Pantanal, but with special attention to the salines widely used by many flocks of aquatic birds (mainly in the dry season) and migrant and/or rare species restricted to this habitat.
\end{abstract}

Keywords: Heterogeneity, conservation, dynamics, aquatic birds, Pantanal.

\section{Distribuição, composição e sazonalidade das aves aquáticas na sub-região da Nhecolândia, Pantanal Sul, Brasil}

\section{Resumo}

Apesar da notável importância do Pantanal para a conservação de aves aquáticas, é pouco conhecido o status de suas populações, seus padrões espaço-temporais de distribuição e uso do habitat e estrutura da comunidade. Assim, foram estudados três ambientes aquáticos (rio Negro, baías e salinas) de 2007 a 2009 no Pantanal da Nhecolândia para verificar se as aves aquáticas diferem na distribuição e composição e também se há influência sazonal significativa sobre estes aspectos. Adotamos o método de transectos lineares durante 288 horas de amostragem e registradas 135 espécies e 7.834 indivíduos. O rio Negro apresentou a maior diversidade e as salinas a menor. A similaridade das comunidades de aves aquáticas foi maior entre baías e salinas, seguida pelo rio Negro e baías e salinas e rio Negro. O equidistribuição é mais variável nas salinas e mais estável no rio Negro. Os ambientes diferem entre si na composição de aves aquáticas no espaço (uso de habitat e distribuição) e tempo (flutuações sazonais de água). A diversidade na estação seca variou significativamente nas salinas, seguido pelas baías, sendo mais estável no rio Negro. No entanto, independentemente da grande amplitude anual de seu fluxo, o rio Negro é o mais estável sazonalmente em relação à comunidade de aves. Isto se deve principalmente pela mata ciliar no rio Negro ser contínua (não isolada) e constante ao longo do ano. Estes aspectos proporcionam melhores condições para as aves se manterem durante todo o ano neste ambiente, contribuindo para diminuir as tendências sazonais nômades de aves aquáticas. Todos estes dados fornecem fortes argumentos para o preservação de todos as fitofisionomias na sub-região da Nhecolândia, mas com especial a atenção para as salinas amplamente utilizadas por muitos bandos de aves aquáticas (principalmente no período seco) e migrantes e/ou espécies raras restritas a este habitat.

Palavras-chave: heterogeneidade, conservação, dinâmica, aves aquáticas, Pantanal. 


\section{Introduction}

The Pantanal shows well defined dry and wet seasons. Flooding occurs across large areas of extravasation of rivers, altering and reconfiguring habitats and landscapes during wet periods (Por, 1995). Pantanal is known as an important breeding site for aquatic birds and their distribution is quite spatio-temporally heterogeneous in different sub-regions and geological formations (Por, 1995).

The Nhecolândia sub-region is marked by the occurrence of large freshwater bays and salt marshes, called salines (Ravaglia et al., 2011). The bays and salines environments, as well as all rivers and interconnections by drainage mesh, present an extremely diverse and abundant biota in different regions and periods of the year (Sucksdorff, 1989). According to Morrison et al. (2008), the bays and salines form an isolated set of all other wet Pantanal environments in terms of bird composition, with significantly high densities in saline areas.

Pantanal is probably the most important wetland in South America to birds associated with aquatic environments and muddy substrates (Scott and Carbonell, 1986). However, despite the remarkable significance of such region for the conservation of resident and migratory birds, the spatiotemporal patterns of distribution, habitat use, structure of bird communities and the status of populations of aquatic birds are little known in Pantanal (Tubelis and Tomas, 2003; Junk et al., 2006; Figueira et al., 2006; Oliveira, 2006). According to Morrison et al. (2008) the seasonality in Pantanal plays a major role in bird distribution, but the patterns of distribution related to seasonality are still poorly understood.

Thus, the present study attempts to answer the following questions: 1) Does the aquatic environments host different composition of aquatic birds? 2) Is there significant seasonal variation in the community of aquatic birds?

\section{Material and Methods}

\subsection{Study area}

The study was conducted at Reserva de Patrimônio Privado Natural Fazenda Rio Negro, in Nhecolândia subregion of Pantanal, municipality of Aquidauana, Mato Grosso do Sul. The Nhecolândia sub-region is located at the south-central portion of Pantanal, in the south portion to the Taquari River $\left(19^{\circ} 30^{\prime} \mathrm{S}, 56^{\circ} 12.5^{\prime} \mathrm{W}\right)$. It is characterized by slightly higher land than its surroundings, with moderate localized floods of short duration, where the bays and salines are dispersed in a quite heterogeneous environment (Adámoli, 1982). The climate is tropical sub-humid, with average annual rainfall of $1.180 \mathrm{~mm}$ and average temperatures ranging from 21 to $28^{\circ} \mathrm{C}$ (Soriano and Alves, 2005). There is a remarkable dry season between May and September and wet season between November and March. The Fazenda Rio Negro houses a wide variety of environments, representing the major habitats found in this sub-region of Pantanal: grassland, strict sense savanna, semideciduous dry forest or woodland, riparian forest, the
Negro river, bays and salines. The environments used for aquatic birds sampling were: Negro river, bays and salines.

The Negro river is a tributary of the Paraguay river, with dark colored water and sandy substrate. Both terrestrial and submerged riparian forest contributes to the formation of structurally heterogeneous vegetation. Riparian vegetation promotes both higher plant matter input and formation of microenvironments with trunks and branches deposited on the banks and into the water body. There are also islands of floating aquatic vegetation called "camalotes". The Negro river shows an average flow of $75 \mathrm{~m}^{3} / \mathrm{s}$, with large annual amplitude, reaching less than $1 \mathrm{~m}^{3} / \mathrm{s}$ in the dry season (Por, 1995).

The bays are natural freshwater spots, circular or elongated shaped and isolated by small elevations on ground, covered by vegetation or not. Waters from various bays connect to each other and to rivers through small passages ("corixos" and "vazantes"), forming a coalescent system during the flood. In general, the bays are slightly acidic to slightly alkaline, with a diverse composition of phytoplankton, microcrustaceans and intense colonization by macrophyte and graminoid vegetation (Mourão, 1989; Eaton, 2006).

Salines are circular or elongated on shape. They are natural and alkaline freshwater bodies with large amounts of dissolved sodium carbonate. They are isolated by elevations on the ground and do not connect to other reservoirs or rivers during flood. In general, the salines are dynamic bodies that fill up during wet season and become waterless during dry season, leaving muddy banks used by shorebirds (Morrison et al., 2008). Phytoplankton biomass, primary productivity and chlorophyll concentration in the salt can be extremely high, compared to most productive aquatic ecosystems in the world (Mourão, 1989). Diversity of algae and microcrustaceans is generally lower than in bays, but it may present unique species in this environment, with blue-green algae predominance (Eaton, 2006).

\subsection{Sampling}

Sampling was performed in four bays and four salines, distant about $5 \mathrm{~km}$ from each other. Samplings at Negro river were made with an aluminum boat in constant speed in four distinct parts: two in the upper portion and two in the lower portion of the river. These samples were collected from January 2007 to December 2009. The methodology used was the linear transects (Bibby et al., 1992) with two hours (equivalent to 1 sample), speed average of $2 \mathrm{~km} \cdot \mathrm{h}^{-1}$, always in the morning (between 5:00 and 9:30). We performed surveys of 48 samples for each environment and 144 samples for all environments. All birds observed within the environment or their banks were recorded. The gregarious birds were visually divided into sectors or quadrants to facilitate counting of individuals, according to Bibby et al. (1992). The nomenclature of species follows the Brazilian Ornithological Records Committee (CBRO, 2011). The analyzes included only those species that feed predominantly in water - diving, 
swimming or flying over water surface - and also on the banks or mud (adapted from Junk et al., 2006).

\subsection{Data analysis}

The parameters used to analyze the structure of bird communities were: Richness (S), Abundance (N), Density Index (ID - individuals / hour), Shannon-Wienner (H'), Equidistribution (E), and Jaccard similarity index (ISJ). All parameters follow Magurran (1988).

Species recorded only once or those occurred in only one sample were excluded from statistical analyzes. We used pre-Kruskal-Wallis $(\mathrm{H})$ and Dunn's post-test at $\mathrm{p}$ $<0.05$ to compare three years and three environments in relation to richness, abundance and diversity index.

We performed an analysis of ordering using monthly abundance of species in three habitats studied. Thus, transformation was performed $(\mathrm{Ln}=\mathrm{Y}(\mathrm{x}+1))$ for data normalization and from this transformation the principal components analysis (PCA) was calculated. Only species that showed higher scores of 0.01 were considered in PCA (Table 1). Information about food niche and ecology of each bird species were obtained by observations in situ and data from the literature (e.g. Willis, 1979; Sick, 1997).

\section{Results}

We performed 288 hours of observations from 2007 to 2009 (96 per environment). We recorded 13.416 contacts belonging to 279 species and 55 families. 135 species and 7.834 individuals (about 60\%) were aquatic birds (Table 1). The highest abundance (Table 2) was recorded in the salines, with 5056 individuals, followed by the Negro river and bays, 1771 and 720 individuals, respectively (Figure 1a). However, the richness was very different in the three environments: 153 species in the bays (43 aquatic birds), 138 in the salines (45), and 156 in the river (45) (Figure 1b).

The richness was different among aquatic environments $(H=15.68, p<0.001)$. Negro river differed from salines $(\mathrm{p}=0.000)$ and bays $(\mathrm{p}=0.002)$, but no significant differences were observed between salines and bays. The habitats differ from each other in relation to the diversity indices $(H=14.45, \mathrm{p}<0.001)$. Differences were more significant only between salines and Negro river $(H=21.5$, $\mathrm{p}=0.000)$ and bay $(\mathrm{H}=23.5, \mathrm{p}=0.02)$. The highest values of $\mathrm{E}$ were obtained in the bays and Negro river. The salines showed a lower value of $25 \%$. The abundance also differed

Table 1. Number of individuals per species with more than one occurrence in two of three environments. The values were obtained from the principal component analysis for components 1 and 2. All the species were included since they were registered at least in one environment.

\begin{tabular}{|c|c|c|c|c|c|}
\hline \multirow{2}{*}{ Species } & \multicolumn{3}{|c|}{ Habitat } & \multicolumn{2}{|c|}{ Components } \\
\hline & Salines & Negro river & Bays & 1 & 2 \\
\hline Tachybabtus dominicus (Linnaeus, 1766) & 591 & 1 & 8 & -0.10 & 0.08 \\
\hline Phalacrocorax brasilianus (Gmelin, 1789) & 35 & 682 & 18 & 0.13 & 0.08 \\
\hline Anhinga anhinga (Linnaeus, 1766) & 21 & 398 & 4 & 0.21 & 0.08 \\
\hline Syrigma sibilatrix (Temminck, 1824) & 94 & 2 & 13 & -0.09 & 0.08 \\
\hline Pilherodius pileatus (Boddaert, 1783) & 0 & 29 & 9 & 0.01 & -0.07 \\
\hline Ardea cocoi Linnaeus, 1766 & 4 & 311 & 15 & 0.17 & 0.00 \\
\hline Ardea alba Linnaeus, 1758 & 469 & 220 & 26 & 0.05 & 0.17 \\
\hline Bubulcus ibis (Linnaeus, 1758) & 42 & 19 & 4 & -0.02 & 0.06 \\
\hline Egretta thula (Molina, 1782) & 545 & 85 & 61 & -0.06 & 0.23 \\
\hline Butorides striata (Linnaeus, 1758) & 10 & 245 & 21 & 0.18 & 0.01 \\
\hline Nycticorax nycticorax (Linnaeus, 1758) & 17 & 20 & 0 & 0.03 & 0.07 \\
\hline Cochlearius cochlearius (Linnaeus, 1766) & 2 & 31 & 2 & 0.02 & -0.04 \\
\hline Tigrisoma lineatum (Boddaert, 1783) & 4 & 81 & 8 & 0.11 & 0.04 \\
\hline Egretta caerulea (Linnaeus, 1758) & 10 & 2 & 1 & -0.02 & 0.01 \\
\hline Mycteria americana Linnaeus, 1758 & 9 & 66 & 1 & 0.03 & 0.07 \\
\hline Ciconia maguari (Gmelin, 1789) & 5 & 2 & 3 & -0.01 & -0.01 \\
\hline Jabiru mycteria (Lichtenstein, 1819) & 13 & 34 & 7 & 0.04 & 0.09 \\
\hline Heliornis fulica (Boddaert, 1783) & 0 & 2 & 3 & 0.01 & -0.01 \\
\hline Phimosus infuscatus (Lichtenstein, 1823) & 140 & 131 & 14 & -0.01 & 0.15 \\
\hline Plegadis chihi (Vieillot, 1817) & 37 & 4 & 15 & -0.04 & 0.08 \\
\hline Theristicus caerulescens (Vieillot, 1817) & 43 & 8 & 7 & -0.02 & 0.05 \\
\hline Theristicus caudatus (Boddaert, 1783) & 79 & 19 & 11 & -0.04 & 0.12 \\
\hline Mesembrinibis cayennensis (Gmelin, 1789) & 114 & 18 & 3 & -0.03 & 0.13 \\
\hline Platalea ajaja Linnaeus, 1758 & 226 & 72 & 7 & -0.06 & 0.13 \\
\hline Dendrocygna viduata (Linnaeus, 1766) & 857 & 28 & 156 & -0.14 & 0.16 \\
\hline Dendrocygna autumnalis (Linnaeus, 1758) & 215 & 223 & 24 & 0.00 & 0.25 \\
\hline
\end{tabular}


Table 1. Continued...

\begin{tabular}{|c|c|c|c|c|c|}
\hline \multirow{2}{*}{ Species } & \multicolumn{3}{|c|}{ Habitat } & \multicolumn{2}{|c|}{ Components } \\
\hline & Salines & Negro river & Bays & 1 & 2 \\
\hline Dendrocygna bicolor (Vieillot, 1816) & 3 & 0 & 3 & -0.01 & -0.02 \\
\hline Cairina moschata (Linnaeus, 1758) & 22 & 38 & 12 & & \\
\hline Amazonetta brasiliensis (Gmelin, 1789) & 148 & 4 & 16 & -0.11 & 0.13 \\
\hline Chauna torquata (Oken, 1816) & 0 & 21 & 17 & 0.00 & -0.04 \\
\hline Rostrhamus sociabilis (Vieillot, 1817) & 13 & 3 & 3 & -0.02 & 0.01 \\
\hline Aburria cumanensis (Jacquin, 1784) & 38 & 316 & 5 & 0.17 & 0.12 \\
\hline Aramus guarauna (Linnaeus, 1766) & 0 & 19 & 5 & 0.03 & 0.03 \\
\hline Aramides cajanea Statius Muller, 1776) & 7 & 72 & 10 & 0.09 & 0.08 \\
\hline Jacana jacana (Linnaeus, 1766) & 121 & 27 & 103 & -0.06 & 0.09 \\
\hline Vanellus cayanus (Latham, 1790) & 2 & 220 & 2 & 0.17 & 0.11 \\
\hline Charadrius collaris Vieillot, 1818 & 0 & 38 & 2 & 0.04 & 0.02 \\
\hline Tringa flavipes (Gmelin, 1789) & 485 & 0 & 0 & -0.09 & 0.16 \\
\hline Tringa melanoleuca (Gmelin, 1789) & 208 & 2 & 5 & -0.07 & -0.01 \\
\hline Tringa solitaria Wilson, 1813 & 2 & 7 & 9 & & \\
\hline Calidris himantopus (Bonaparte, 1826) & 3256 & 60 & 30 & -0.26 & 0.20 \\
\hline Phaetusa simplex (Gmelin, 1789) & 269 & 281 & 11 & 0.06 & 0.25 \\
\hline Sternula superciliaris (Vieillot, 1819) & 9 & 93 & 12 & 0.05 & 0.00 \\
\hline Rynchops niger Linnaeus, 1758 & 0 & 219 & 4 & 0.11 & 0.05 \\
\hline Crotophaga major Gmelin, 1788 & 25 & 319 & 36 & 0.10 & -0.12 \\
\hline Megaceryle torquata (Linnaeus, 1766) & 0 & 564 & 6 & 0.25 & 0.00 \\
\hline Chloroceryle amazona (Latham, 1790) & 2 & 436 & 6 & 0.22 & -0.04 \\
\hline Chloroceryle americana (Gmelin, 1788) & 0 & 92 & 3 & 0.14 & 0.01 \\
\hline Synallaxis albilora Pelzeln, 1856 & 0 & 46 & 1 & 0.09 & 0.02 \\
\hline Neopipo cinnamomea (Lawrence, 1869) & 0 & 13 & 6 & 0.02 & 0.04 \\
\hline Phacellodomus rufifrons (Wied, 1821) & 7 & 3 & 1 & & \\
\hline Cercomacra melanaria (Ménétriès, 1835) & 0 & 83 & 1 & 0.12 & 0.05 \\
\hline Tachycineta albiventer (Boddaert, 1783) & 0 & 76 & 5 & 0.10 & 0.07 \\
\hline Pygochelidon cyanoleuca (Vieillot, 1817) & 0 & 84 & 12 & 0.05 & -0.05 \\
\hline Stelgidopteryx ruficollis (Vieillot, 1817) & 0 & 238 & 39 & 0.14 & 0.05 \\
\hline Campylorhynchus turdinus (Wied, 1831) & 36 & 15 & 6 & & \\
\hline Donacobius atricapillus (Linnaeus, 1766) & 26 & 69 & 5 & 0.04 & -0.01 \\
\hline Agelasticus cyanopus (Vieillot, 1819) & 0 & 8 & 26 & & \\
\hline $\begin{array}{l}\text { Paroaria capitata (d'Orbigny \& } \\
\text { Lafresnaye,1837) }\end{array}$ & 0 & 236 & 30 & 0.18 & 0.08 \\
\hline Paroaria coronata (Miller, 1776) & 0 & 40 & 3 & 0.05 & 0.03 \\
\hline
\end{tabular}

between environments $(H=16.18, p<0.001)$, whereas the number of individuals in the bays was significantly different from salines $(\mathrm{p}=0.002)$ and Negro river $(\mathrm{p}=$ $0.000)$. No difference was observed between salines and Negro river. The density index obtained in salines was 107.1, followed by Negro river (72.7) and bays (16.8).

The most abundant species in each environment corresponded to $50 \%$ of all records. D. viduata $(\mathrm{n}=137)$, J. jacana $(\mathrm{n}=135)$, E. thula $(\mathrm{n}=46), D$. autumnalis $(\mathrm{n}=46)$ and B. striata $(\mathrm{n}=40)$ were most abundant in bays. H. melanurus was the most abundant species, with $98 \%$ of its records in salines, followed by $T$. flavipes $(n=468)$ with records only in salines. These two species alone were responsible for approximately $52 \%$ of total abundance in the salines. In the Negro river, P. brasilianus $(\mathrm{n}=340)$, M. torquata $(\mathrm{n}=201), C$. amazona $(\mathrm{n}=146)$, $A$. $\operatorname{cocoi}(\mathrm{n}=139)$ and $R$. niger $(\mathrm{n}=128)$ were the most abundant. Recurvirostridae (only $H$. melanurus with $\mathrm{n}=2170$ individuals), followed by Ardeidae, with 11 species $(n=1226)$ and eight Anatidae species $(n=1052)$ were the most abundant families.

The Jaccard Similarity Index was higher between bays and salines (ISJ $=73 \%$ ), followed by Negro river and bays $(71 \%)$ and lower between salines and Negro river (59\%). E was divergent among different environments, with more disparate values for salines and more stable for the Negro river. 32 aquatic species (55\% of total) were recorded in the three environments, 12 species $(21 \%)$ in two and 15 species $(24 \%)$ only in one of three environments: C. torquata, B. nigricollis and Jabiru mycteria 
Table 2. Most abundant species (over 10 records) in the bays, salines e Negro river environments at Fazenda Rio Negro between 2007 and 2009.

\begin{tabular}{lclclc}
\hline \multicolumn{1}{c}{ Species } & Bays & \multicolumn{1}{c}{ Species } & Salines & \multicolumn{1}{c}{ Species } & Negro river \\
\hline Dendrocygna viduata & 137 & Himantopus melanurus & 2145 & P. brasilianus & 340 \\
Jacana jacana & 135 & Tringa flavipes & 468 & Megaceryle torquata & 201 \\
Egretta thula & 46 & Dendrocygna viduata & 428 & Chloroceryle amazona & 146 \\
D. autumnalis & 46 & Ardea alba & 337 & Ardea cocoi & 139 \\
Butorides striata & 40 & Tachybabtus dominicus & 255 & Rynchops niger & 128 \\
Ardea alba & 37 & Egretta thula & 202 & Vanellus cayanus & 110 \\
Vanellus chilensis & 32 & Phaetusa simplex & 199 & Anhinga anhinga & 106 \\
P. brasilianus & 25 & Platalea ajaja & 169 & Ardea alba & 97 \\
Himantopus melanurus & 25 & Dendrocygna autumnalis & 144 & Butorides striata & 91 \\
Phaetusa simplex & 25 & Vanellus chilensis & 135 & Dendrocygna autumnalis & 75 \\
Ardea cocoi & 22 & Amazonetta brasiliensis & 104 & Phaetusa simplex & 53 \\
Phimosus infuscatus & 20 & Tringa melanoleuca & 84 & Tigrisoma lineatum & 48 \\
Chauna torquata & 20 & Phimosus infuscatus & 83 & Chloroceryle americana & 43 \\
Busarellus nigricollis & 18 & Syrigma sibilatrix & 63 & Phimosus infuscatus & 41 \\
Syrigma sibilatrix & 16 & Jacana jacana & 61 & Dendrocygna viduata & 30 \\
Plegadis chihi & 14 & Plegadis chihi & 52 & Egretta thula & 29 \\
Cairina moschata & 14 & M. cayennensis & 30 & Mycteria americana & 21 \\
Amazonetta brasiliensis & 14 & P. brasilianus & 26 & Aramides cajanea & 20 \\
Theristicus caudatus & 12 & Cairina moschata & 25 & Vanellus chilensis & 18 \\
Sterna superciliaris & 12 & Theristicus caerulescens & 24 & Sternula superciliaris & 18 \\
Jabiru mycteria & 10 & Theristicus caudatus & 22 & Cairina moschata & 17 \\
Total & 720 & & 5056 & & \\
\hline
\end{tabular}
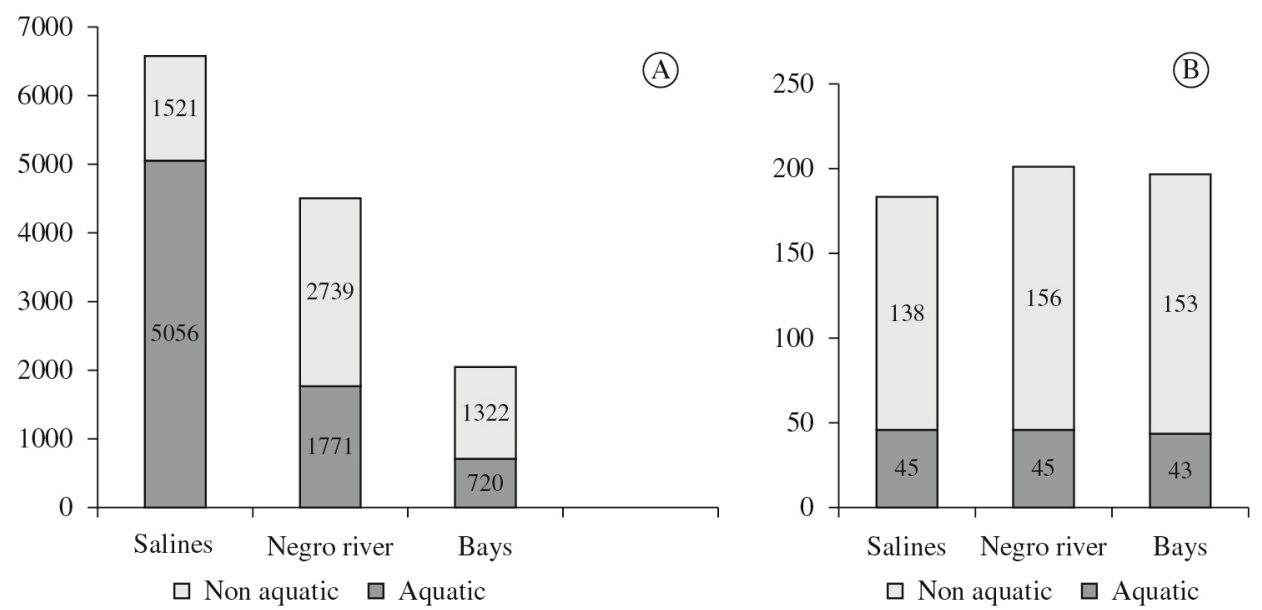

Figure 1. Abundance and richness of birds sampled in aquatic environments at Fazenda Rio Negro. A - Total abundance by environment; B - Total richness by environment. Light bars refer only to aquatic species and dark bars refer to other bird species.

(bays); T. dominicus, T. melanoleuca, M. cayanensis, T. caerulescens (salines). In addition, D. bicolor, S. sylvicola, C. leucophrys, C. coscoroba, A.macularius showed less than ten records for each species in the salines; as well as $M$. torquata, C. amazona, $R$. Niger, V. cayanus, T. lineatum, $C$. americana, $M$. americana and $A$. cajanea in Negro river. Moreover, P. pileatus, C. cochlearius, B. pinnatus, $H$. fulica, $P$. halietus, $P$. nigricans and $C$. inda presented less than ten records for each species in the Negro river.
The Negro river had the second largest ID. Fifteen species presented more than 100 records. P. brasilianus was the most abundant species, with 340 records. In addition to aquatic species, numerous forest or vagrant species presented abundant records in the Negro river, as well as $O$. canicollis and C. major. The latter two are frequently recorded in forest edges, while $O$. canicollis is registered on the beaches of Negro river in the dry season. C. major 
is always observed on banks beyond the edges of forest land along the river.

PCA (eingevalue $=42.6$; variance $=29.5$ ) defined three distinct groups for the three habitat types studied (Figure 2). Negro river presented the highest diversity, while salines the lowest and the bays remained between these two extremities.

Salines showed the highest difference to richness and abundance between dry and wet seasons. 29 species were recorded in the wet and 40 in the dry season (Figure $3 \mathrm{a}$ ). 3376 individuals were recorded in the dry and 1764 in the wet season (Figure 3b).

There was a strong variation between seasons for both richness and abundance averages (Figures $3 \mathrm{c}$ and $3 \mathrm{~d}$ ). The salines showed the highest variation for average abundance between periods. However, significant difference between the dry and wet periods was found only for bays $(\mathrm{U}=1409, \mathrm{p}=0.001)$. Seasonal variation in composition of bird community was higher in the salines, with $49 \%$ of similarity between the dry and wet periods. Other environments showed similarity of $64 \%$ (Negro river) and $72 \%$ (bays) between seasons.

\section{Discussion}

The seasonal fluctuation in abundance and richness of birds was more pronounced in the salines. T. dominicus, with 221 records in the dry and 34 in the wet season, showed the most differences in occurrence between periods. C. leucophry and A. macularius were recorded only in wet season. T. flavipes occurs only in the saline and together with $H$. melanurus were the most abundant species in this environment. The conditions of mud banks in the salines seem to provide the ideal foraging sites to these species.
The bird aggregation appears in dormitories and breeding colonies, usually in bounds, sandbars in rivers or in large trees at the marginal water bodies (Sick, 1997). In addition, such species were present between $60 \%$ and $80 \%$ of the campaigns during the three years of sampling, totaling 2638 records. $H$. melanurus was also the most abundant species in the study of Morrison et al. (2008), representing $70 \%$ of the total sample and widely distributed in other regions. According to Gaston (1994), locally abundant species with wide distribution use resources equally abundant and well distributed, while locally rare species that occupy few sites use more scarce resources. Bird aggregations can also provide better foraging success (Battley et al., 2003) and also lower predation risks (Caldwell, 1986). According to Junk et al., (2006), censuses in Pantanal have identified colonies with over 10.000 individuals. These authors state that 17 aquatic bird species breed in colonies in Pantanal, especially kingfishers, terns, black skimmers, storks, herons and spoonbills.

S. sylvicola, C. leucophrys, C. coscoroba, E. caerulea, $C$. himantopus and A. macularius were recorded only in the salines. Sick (1997), Tubelis and Tomas (2003) noted that records of $C$. coscoroba are scarce in Pantanal, nevertheless Morrison et al. (2008) report recent records in Nhecolândia bays. Nunes (2011) registered the first records $(\mathrm{n}=2)$ of $C$. himantopus to the Pantanal. P. ajaja is the most abundant Treskiornithidae species, almost exclusively in salines. $P$. simplex were very abundant in the salines, but it was recorded in the three environments.

Negative correlation observed between Index of Density (ID) and equidistribution (E) indicates that communities with higher abundance showed lower E due to high ID found in some communities, mainly as a consequence of species dominance such as $H$. melanurus and $D$. viduata

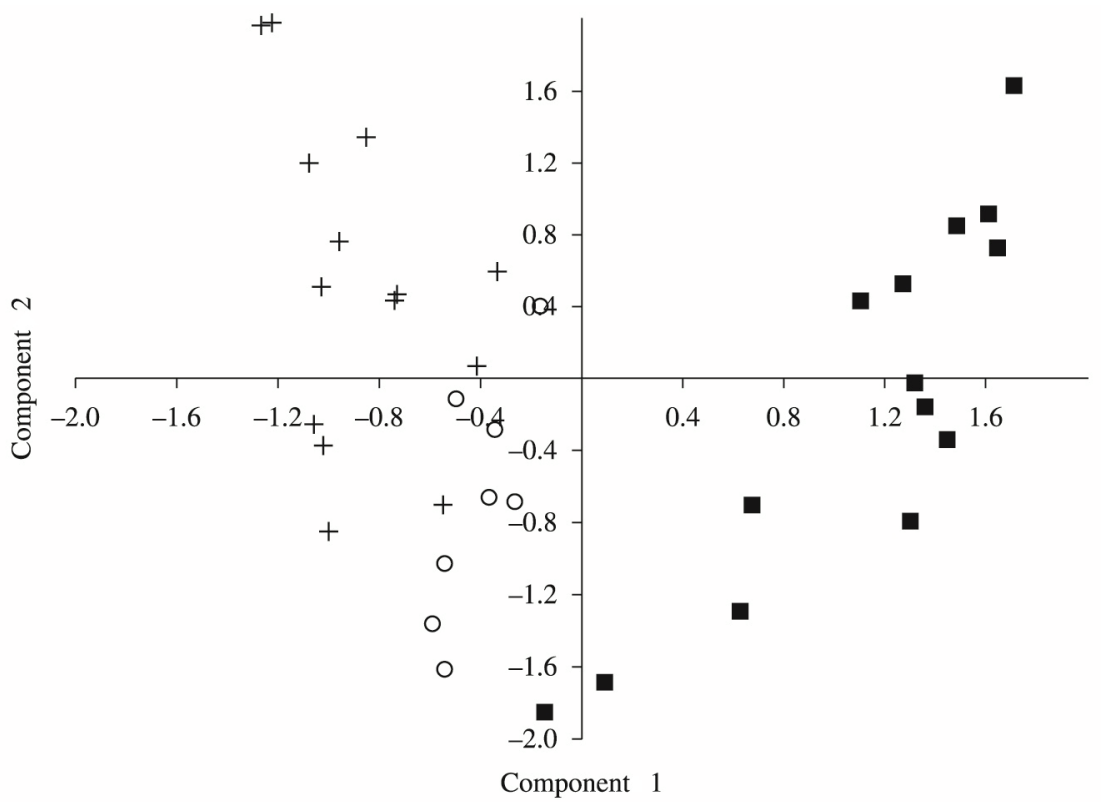

Figure 2. Results from PCA according to occurrence and abundance of species: $+=$ salines, $\mathrm{O}=$ bays and $=$ Negro River. 

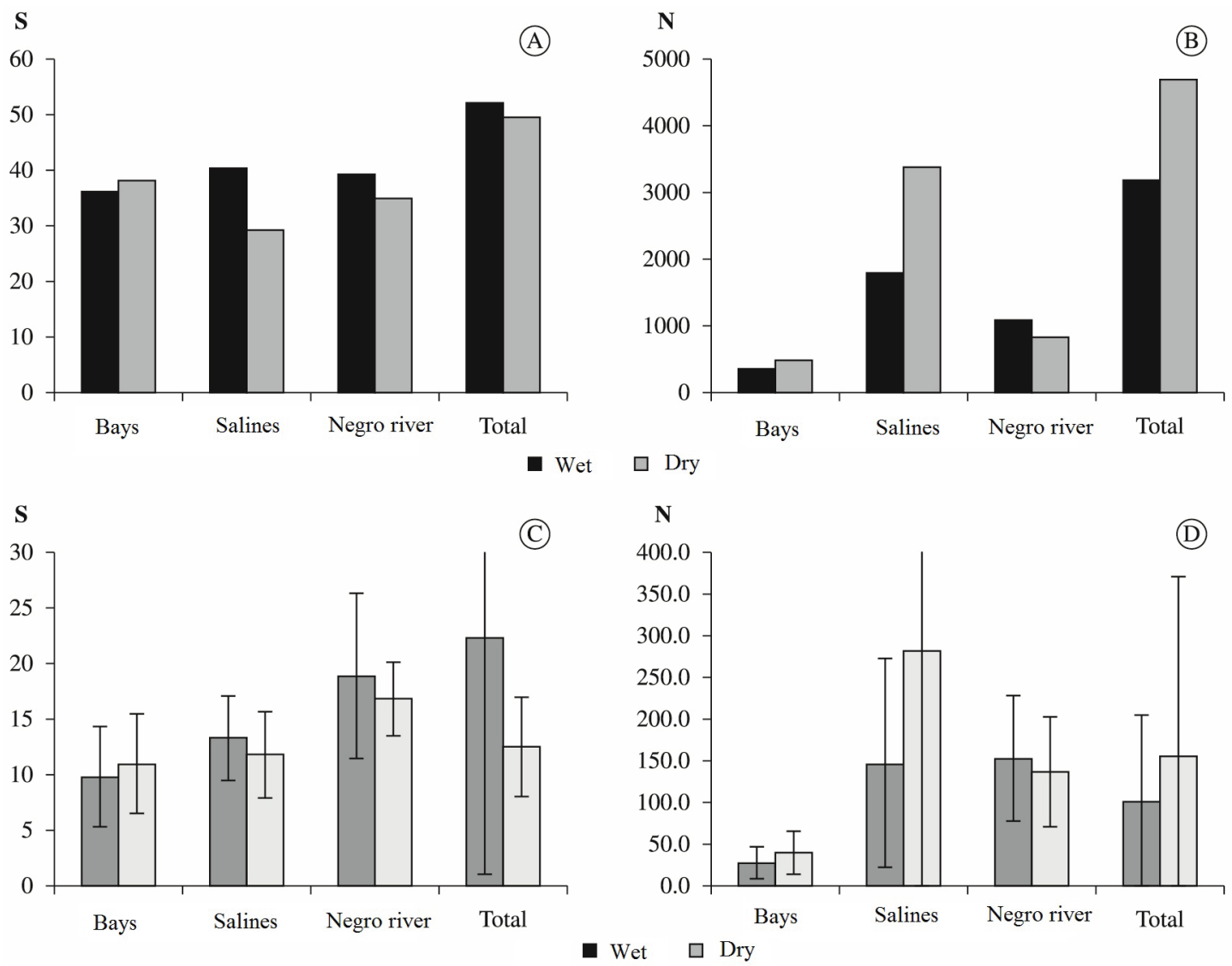

Figure 3. Richness and abundance of birds in three aquatic environments at Fazenda Negro river A - total richness, B - total abundance, $\mathrm{C}$ - richness average, D - abundance average. In $\mathrm{C}$ and $\mathrm{D}$, bars indicate standard deviation.

in salines, P. brasilianus, and M. torquata in the Negro river. However, a high number of species with significant abundance (seven species with more than 100 records) enabled the Negro river index of E not as low as that of the salines. In fact, Negro river houses a multitude of species whose habit is not exclusively aquatic.

In the bays, the richness was associated with significant most uniform abundances, increasing the equidistribution. Two species have excelled in abundance: $D$. viduata and $J$. jacana that often use the floating vegetation. Morrison et al. (2008) found J. jacana mostly lowland, covering a wide variety of open aquatic habitats.

P. brasilianus was predominantly found in the Negro river, with some records in the bays and salines, as well as the less abundant $A$. anhinga. Three species of Ardeidae were recorded in the Negro river: $P$. pileatus, $C$. cochlearius and $B$. pinnatus (all with less than ten records). P. halietus was recorded only in the Negro river, corroborating information from Morrison et al. (2008), who recorded it only near major rivers. $R$. niger and all four species of kingfishers were only abundant in the Negro river. The first is found only in the dry season when there are beaches on the shores of rivers that allow the laying of eggs, usually July and August (Sick, 1997).
An expressive richness of birds was observed in aquatic environments and their margins, corresponding to $39 \%$ of the 388 species sampled in the region of Negro river (Donatelli, 2005). However, a total of approximately two thirds of species found on the banks of the Negro river, in the bays and salines are not aquatic birds. It indicates that these environments are often used by a portion of biota far superior than exclusively aquatic species (Donatelli, 2005).

The total richness of aquatic birds ( $\mathrm{n}=135$ species) was higher than found by other authors. Junk et al. (2006) and Nunes and Tomas (2008) and Nunes (2011) found 64 and 114 aquatic species, respectively, in this biome. The high abundance and richness of aquatic birds in the pantanal habitats can be explained by the high abundance and richness of fishes. In fact, the Pantanal is among of the highest diversity biome on fishes in the planet (Conceição and Paula, 1986).

The ID of birds in the salines was 1.5 times higher than in the Negro river and six times higher than in the bays. The richness of aquatic birds was quite similar among the three sampled groups. However, the composition was considerably different, especially between Negro river and salines. The richness was higher in the Negro river, but the 
abundance of birds was approximately five times higher in the salines. These differences are most probably due to the physical, chemical and biological properties between these environments: the salines have very high primary productivity and inhospitable physicochemical conditions (Eaton, 2006). According to this author, the bays show more diverse plankton, invertebrates and macrophytes. As a result, the high primary productivity and low diversity of the salines may have contributed to the huge difference in bird abundance. According to Townsend et al. (2006), environments with moderate primary productivity or resource supply, but without large variety of resources, enable a high abundance and less richness. Since the salines show the most homogeneous pattern, it is expected that the avifauna to explore them would be abundant, but less rich. More than 100.000 shorebirds have been recorded in the salines region (Junk et al., 2006)

According to Ricklefs (1990) aquatic birds showed less habitat preference than all other species. As a result, it is expected they share many bird species in common. However, when compared to the Negro river and bays, aquatic birds found in the salines were surprisingly high on richness. In addition, density in bays was significantly higher as mentioned by Donatelli (2004). The diversity index of the salines was the lowest among the three environments, as there is a large number of individuals distributed in the species. Therefore, the diversity of a given environment is closely related to the equidistribution, as here observed: the individuals are more equitably distributed in the Negro river, less equitably in the bays and much less in the salines.

Oliveira (2006) reported that during the Pantanal flooding cycle the fauna invade the floodplains from more stable and safer, non-flooding habitats, creating sporadic but ephemeral populational increases. Acctually, Pantanal presents intense seasonal periods and it can result in strong selective pressures, increasing competition among species (Eiten, 1993) which forces them to use different environments to support resource scarcity (Brown Junior, 1986). Some authors explain certain bird movements among habitats based on this assertion (Malizia, 2001; Figueira et al., 2006; Accordi and Hartz, 2006). Moreover, no correlation was found by Figueira et al. (2006) between aquatic bird abundance and the number of months in which seasonal species occurred, suggesting that for the pantanal of Poconé no optimal period exists for all seasonal species. However, the analysis obtained here indicates that the three environments (Negro river, bays and salines) have specific bird species adapted to the environmental conditions of each habitat, even when considering different seasons.

Large aggregations of birds are quite common at the end of wet season, called the ebb period. During this period, the water level is low and encloses fishes and other organisms in small channels and bays, making them easy prey for birds, alligators and other animals (Brasil,
1997). Malizia (2001) reports an increase of diversity during the rainy season for being the reproductive period of Neotropical birds and also an increase in the amount of food available. However, as shown in our results, there is an inverse correlation to the hypotheses above. In Nhecolândia, we observed highest diversity and abundance of aquatic birds during the dry season in wetland due to the scarcity of resources, especially water and food, which facilitates concentration of aquatic birds in wet environments during this period. The same is observed by Oliveira (2006) that found the abundance of aquatic bird increases as the amount of rain (pluviosity) decreases in the Pantanal of Poconé. Furthermore, migratory species are observed more frequently in humid areas during dry periods, since they use these specific locations at times of food scarcity (Accordi and Hartz, 2006). In fact there are migrations of aquatic birds in response to significant variation in water level and resource availability, such as wood storks, egrets, terns, ducks, sandpipers and swallows (Oliveira, 2006).

The different aquatic studied environments present the community of birds with relatively distinct structure and particular abundance. The composition and abundance of species varied significantly according to season, mainly in the salines, followed by the bays. However, these are more stable in the Negro river, which also differs from the habitats concerning other calculated parameters. Nevertheless, we noticed remarkable variations on the community structure of aquatic birds concerning seasonal changes, as well as a high diversity due to the mosaic of aquatic habitats presented in Pantanal.

Mosaic landscape is more effective for bird diversity conservation since many species were abundantly registered in all habitats, which can be an evidence of flexibility on habitat use (Law and Dickman 1998, Smith et al., 2011; Figueira et al., 2006). Further, the existing heterogeneity in aquatic habitats also creates favorable conditions for the establishment of aquatic birds with different ecological characteristics, resulting in high beta diversity (Moreno and Halffter 2001, Balvanera et al., 2002, Veech, 2005. Finally, we observed that the environmental heterogeneity creates favorable conditions for the establishment of many aquatic birds all year.

On the other hand, we also observed many species restricted to a single habitat. In this way, we would like to point out the importance of preservation of salinas for conservation of the aquatic birds since rare species to the Pantanal are restricted to this habitat. Likewise, the salinas are widely used by many flocks and migrant aquatic birds (mainly in the dry season).

In conclusion, all these data provide strong arguments to the preservation of all phytophysiognomies in the Nhecolândia sub- region of Pantanal, but with special attention to the salinas. This heterogeneity is crucial for the diversity conservation of aquatic birds in this region. 


\section{References}

ACCORDI, IA. and HARTZ, SM., 2006. Distribuição espacial e sazonal da avifauna em uma área úmida costeira do sul do Brasil. Revista Brasileira de Ornitologia, vol. 14, no. 2, p. 117-135.

ADÁMOLI, J., 1982. O Pantanal e suas relações fitogeográficas com os cerrados. Discussão sobre o conceito de "Complexo do Pantanal". In Anais do XXXII Congresso Nacional de Botânica, 1982. Teresina. Teresina: Sociedade Brasileira de Botânica. p. 109-119.

BALVANERA, P., LOTT, E., SEGURA, G., SIEBE, C. and ISLAS, A., 2002. Patterns of diversity in a Mexican tropical dry forest. Journal of Vegetable Science, vol. 13, no. 2, p. 145-158. http://dx.doi.org/10.1111/j.1654-1103.2002.tb02034.x.

BATTLEY, PF., POOT, M., WIERSMA, P., GORDON, C., NTIAMOA-BAIDU, Y. and PIERSMA, T., 2003. Social foraging by waterbirds in shallow coastal lagoons in Ghana. Waterbirds, vol. 26, no. 1, p. 26-34. http://dx.doi.org/10.1675/15244695(2003)026[0026:SFBWIS]2.0.CO;2.

BIBBY, CJ., BURGESS, ND. and HILL, DA., 1992. Bird Census Techniques. San Diego: Academic Press Inc. 257 p.

Brasil. Ministério do Meio Ambiente, dos Recursos Hídricos e da Amazônia Legal. Secretaria de Coordenação dos Assuntos de Meio Ambiente. Programa Nacional do Meio Ambiente. Projeto Pantanal, 1997. Plano de Conservação da Bacia do Alto Paraguai (Pantanal): PCBAP. Brasília: PNMA. Diagnóstico dos meios físico e biótico, vol. 2.

BROWN JUNIOR, KS., 1986. Zoogeografia da região do Pantanal Mato-Grossense. In Anais do I Simpósio Sobre Recursos Naturais e Sócio-econômicos do Pantanal, 1986. Brasília .Brasília: Embrapa-CPAP. p. 137-178.

CALDWELL, GS., 1986. Predation as a selective force on foraging herons: effects of plumage color and flocking. The Auk, vol. 103, no. 1, p. 494-505.

Comitê Brasileiro de Registros Ornitológicos - CBRO, 2011. Lista de aves do Brasil. 9th ed. Versão 18 Oct 2010. Available from: <http://www.cbro.org.br/CBRO/listabr.htm>. Access in: 18 July 2011.

CONCEIÇÃO, CA. and PAULA, JE.,1986, Contribuição para o conhecimento da flora do Pantanal Mato-Grossense e sua relação com a fauna e o homem. In Anais do 1o Simpósio Sobre Recursos Naturais e Sócio-econômicos do Pantanal, 1986. Brasília. Brasília: EMBRAPA-CPAP. p. 107-130

DONATELLI, RJ., 2004. Birds and dynamics habitat mosaics in the Pantanal. Boston: Earthwatch Institute/Pantanal Conservation Research Initiative. Annual Report.

DONATELLI, RJ., 2005. Birds and dynamics habitat mosaics in the Pantanal. Boston: Earthwatch Institute/Pantanal Conservation Research Initiative. Annual Report.

EATON, DP., 2006. Contribuição para conservação de macroinvertebrados, peixes, e hábitats de água doce no Pantanal de Nhecolândia e do Rio Negro, Mato Grosso do Sul. Ensaios e Ciência (Campo Grande), vol. 10, p. 99-118.

EITEN, G., 1993. Vegetação do Cerrado. In NOVAES PINTO, M. Cerrado: caracterização, ocupação e perspectivas. Brasília: Universidade de Brasília/SEMATEC. p. 17-73.

FIGUEIRA, JEC., CINTRA, R., VIANA, LR. and YAMASHITA, C., 2006. Spatial and temporal patterns of bird species diversity in the Pantanal of Mato Grosso, Brazil: implications for conservation. Revista Brasileira de Biologia = Brazilian Journal of Biology, vol. 66, no. 2a, p. 393-404. http://dx.doi.org/10.1590/S151969842006000300003 .

GASTON, KJ., 1994. Rarity. London: Chapman and Hall. 283 p.

JUNK, WJ., CUNHA, CN., WANTZEN, KM., PETERMANN, P., STRUSSMANN, C., MARQUES, MI. and ADIS, J., 2006. Biodiversity and its conservation in the Pantanal of Mato Grosso, Brazil. Aquatic Sciences, vol. 68, no. 3, p. 278-309. http://dx.doi. org/10.1007/s00027-006-0851-4.

LAW, BS. and DICKMAN, CR., 1998. The use of habitat mosaics by terrestrial vertebrate fauna: implications for conservation and management. Biodiversity and Conservation, vol. 7, no. 3, p. 327-333. http://dx.doi.org/10.1023/A:1008877611726.

MAGURRAN, AE., 1988. Ecological diversity and its measurement. New Jersey: Princeton University Press. 178 p.

MALIZIA, LR., 2001. Seasonal fluctuations of birds, fruits and flowers in a Subtropical Forest of Argentina. The Condor, vol. 103, no. 1, p. 45-61. http://dx.doi.org/10.1650/0010-5422(2001)103[0045:SF OBFA]2.0.CO;2.

MORENO, CE. and HALFFTER, G., 2001. Spatial and temporal analysis of alfa, beta and gama diversities of bats in a fragmented landscape. Biodiversity and Conservation, vol. 10, no. 3, p. 367382. http://dx.doi.org/10.1023/A:1016614510040.

MORRISON, RG., SERRANO, I., ANTAS, P. and ROSS, RK., 2008. Aves migratórias no Pantanal: distribuição de aves limícolas neárticas e outras espécies aquáticas no Pantanal. Brasília: WWF-Brasil. 99 p.

MOURÃO, GM., 1989. Limnologia comparativa de três lagoas (duas baías e uma salina) do Pantanal da Nhecolândia, MS. São Carlos: Universidade Federal de São Carlos. Dissertação de Mestrado em Ecologia e Recursos Naturais.

NUNES, AP., 2011. Atualidades Ornitológicas. In AO On-Line. no. 160. Available from: <http://www.ao.com.br >

NUNES, AP. and TOMAS, WM., 2008. Aves migratórias e nômades ocorrentes no Pantanal. Corumbá: Empresa Brasileira de Pesquisa Agropecuária. 122 p.

OLIVEIRA, DM., 2006. Efeitos bióticos e abióticos de ambientes alagáveis nas assembléias de aves aquáticas e piscivoras no Pantanal, Brasil. Manaus: Instituto Nacional de Pesquisas da Amazônia, Universidade do Amazonas. 198 p. Tese de Doutorado.

POR, FD., 1995. The Pantanal of Mato Grosso (Brazil). World largest wetlands. Dordrecht: Kluwer Academic Publishers. 122 p.

RAVAGLIA, AG., SANTOS, S.A., SORIANO, B.M.A., DANIEL, O., FREITAS, L.C., PELLEGRIN, L.A., TOMAS, W.M., RODELA, L.C., BUENO SOBRINHO, AA. and ARAUJO, MTBD., 2011. Mapeamento das Unidades de Paisagem das Sub-regiões da Nhecolândia e Poconé, Pantanal Mato-Grossense. Corumbá: Emprapa Pantanal. 15 p. Embrapa Pantanal. Boletim de Pesquisa e Desenvolvimento, no. 105.

RICKLEFS, RE., 1990. Ecology. New York: W. H. Freeman and Company. 896 p.

SCOTT, DA. and CARBONELL, M., 1986. A Directory of Neotropical Wetlands. Cambridge: IUCN Conservation Monitoring Centre. 684 p.

SICK, H., 1997. Ornitologia Brasileira. Rio de Janeiro: Nova Fronteira. $912 \mathrm{p}$.

SMITH, AC., FAHRIG, L. and FRANCIS, CM., 2011. Landscape size affects the relative importance of habitat amount, habitat fragmentation, and matrix quality on forest birds. Ecography, 
vol. 34, no. 1, p. 103-113. http://dx.doi.org/10.1111/j.16000587.2010.06201.x.

SORIANO, BMA. and ALVES, MJM., 2005. Boletim agrometereológico ano 2002 para a sub-região da Nhecolândia, Pantanal, Mato Grosso do Sul, Brasil. Corumbá: Embrapa Pantanal. 29 p. Embrapa Pantanal. Documentos, no. 76.

SUCKSDORFF, A., 1989. Desenvolvimento e Preservação. II. Visão Nacional. In Anais do I Congresso Internacional sobre Conservação do Pantanal, 1989. Campo Grande. Campo Grande: Governo do Estado de Mato Grosso do Sul/Secretaria de Estado do Meio Ambiente. p. 113-115.
TOWNSEND, C.R., BEGON, M. and HARPER, JL. 2006. Fundamentos em Ecologia. 2nd ed. Porto Alegre: Artmed. 592 p.

TUBELIS, D.P. and TOMAS, W.M., 2003. Birds species of the Pantanal wetland, Brazil. Revista Brasileira de Ornitologia, vol. 11 , no. 1, p. 5-37.

VEECH, JA., 2005. Analyzing patterns of species diversity as departures from random expectations. Oikos, vol. 108, no. 1, p. 149-155. http://dx.doi.org/10.1111/j.0030-1299.2005.13506.x.

WILLIS, EO., 1979. The composition of avian communities in remanescent woodlots in Southern Brazil. Papéis Avulsos de Zoologia, vol. 33, no. 1, p. 1-25. 